\title{
NUTRITIONAL RISK SCREENING IN GASTROENTEROLOGICAL PATIENTS AT THE RIJEKA UNIVERSITY HOSPITAL CENTRE
}

\author{
Sandra Pavičić Žeželj ${ }^{1}$, Danijela Malec ${ }^{2}$, Dolores Janko Labinac ${ }^{3}$, Tamara Šoić Vranić, \\ Gordana Mičetić Balog ${ }^{5}$, Tea Schnurrer-Luke-Vrbanićo, Tea Čaljkušić Mance ${ }^{7}$, \\ Damir Kovačević ${ }^{7}$ and Olga Cvijanović Peloza ${ }^{4}$
}

${ }^{1}$ Department of Health Ecology, University of Rijeka, School of Medicine, Rijeka, Croatia;

${ }^{2}$ Department of Internal Medicine, Rijeka University Hospital Centre, Rijeka, Croatia;

${ }^{3}$ Department of Neurology, Pula General Hospital, Pula, Croatia;

${ }^{4}$ Department of Anatomy, University of Rijeka, School of Medicine, Rijeka, Croatia;

${ }^{5}$ Health Centre of Primorje-Gorski Kotar County, Rijeka, Croatia;

${ }^{6}$ Department of Physical and Rehabilitation Medicine, Rijeka University Hospital Centre, Rijeka, Croatia;

${ }^{7}$ Department of Ophthalmology, Rijeka University Hospital Centre, Rijeka, Croatia

\begin{abstract}
SUMMARY - Malnutrition is usually related to some diseases such as inflammatory bowel disease, chronic pancreatitis, chronic liver disease and malignant tumors. It is characterized by weight loss, protein deficiency, and deficit of specific nutrients. The aim was to estimate the prevalence of nutritional risk among 160 gastrointestinal patients by use of the Nutritional Risk Screening (NRS2002) score at hospital admission and discharge. The patients stayed in the hospital between 5 and 15 days or longer. Results showed that $40 \%$ of patients at admission and $36.2 \%$ at discharge were malnourished. There were $53.1 \%$ of patients with recognized malnutrition at admission that received nutritional support, whereas at discharge $34.4 \%$ of patients at risk were not dietary supported. Malnourished patients were significantly older, had lower body mass index, longer hospital stay and higher rate of malignant diseases than properly nourished patients. Regular screening for malnutrition should be conveyed in hospitals as to provide appropriate dietary support for all patients at risk.
\end{abstract}

Key words: Malnutrition; Gastroenterological patients; Nutrition Risk Screening (NRS 2002)

\section{Introduction}

According to the European Society for Parenteral and Enteral Nutrition (ESPEN), malnutrition is a condition characterized by a structural and functional change of the body composition ${ }^{1}$. Although malnutrition usually means a disease-related weight loss, protein deficiency or deficit of specific nutrients, it can also be related to eating disorders due to suffice of some

Correspondence to: Sandra Pavičić Žeželj, PhD, Department of Health Ecology, University of Rijeka, School of Medicine, Brace Branchetta 20, HR-51000 Rijeka, Croatia

E-mail: sandrapz@medri.uniri.hr

Received September 13, 2018, accepted September 27, 2019 nutrients, such as overweight and obesity ${ }^{1,2}$. Malnutrition is often present in gastrointestinal diseases and carcinoma, and is associated with prolonged hospital stay ${ }^{3}$, higher rate of infection, increasing treatment cost, and increased morbidity ${ }^{4-6}$. On the basis of malnutrition risk assessment, the prevalence of malnourished patients in hospitals ranges from $20 \%$ to $50 \%$. Therefore, early identification and malnutrition care is very important in order to improve outcomes of treatment of diagnosed disease and patient quality of life ${ }^{7,8}$. The majority of studies have shown that during hospital stay, a disease diagnosed in patients is worsened due to inappropriate nutritional support ${ }^{4,9,10}$; on the contrary, when nutritional support is applied, the length of hos- 
Table 1. Patient characteristics and diagnoses according to nutritional risk status $(N=160)$

\begin{tabular}{|c|c|c|c|c|c|}
\hline & Total $(\mathrm{N}=160)$ & \begin{tabular}{|l}
$\mathrm{NRS}<3$ \\
$(\mathrm{~N}=96)$
\end{tabular} & \begin{tabular}{|l|l|}
$\mathrm{NRS} \geq 3$ \\
$(\mathrm{~N}=64)$
\end{tabular} & t-test & $\mathrm{p}$ \\
\hline & \multicolumn{5}{|l|}{ Ar.sr. (SD) } \\
\hline Age (yrs) & $68.8(13.3)$ & $65.9(13.8)$ & $73.2(11.5)$ & 2.53 & $0.014^{*}$ \\
\hline Body height $(\mathrm{cm})$ & $168(9.2)$ & $169.2(9.3)$ & $167.9(9.3)$ & 1.05 & 0.297 \\
\hline Body weight $(\mathrm{kg})$ & $73.9(17.9)$ & $78.9(17.6)$ & $66.3(15.6)$ & 3.39 & $0.001^{*}$ \\
\hline BMI $\left(\mathrm{kg} / \mathrm{m}^{2}\right)$ & $25.9(5.3)$ & $27.5(5.1)$ & $23.7(5.1)$ & 3.26 & $0.002 *$ \\
\hline WHR & $0.94(0.1)$ & $0.94(0.08)$ & $0.93(0.09)$ & 0.61 & 0.558 \\
\hline \multirow[t]{2}{*}{ Mean length of stay } & & 11 & 14 & 2.12 & $0.037^{*}$ \\
\hline & & n (\%) & & $\chi^{2}$ - test & $\mathrm{p}$ \\
\hline \multicolumn{6}{|l|}{ Gender } \\
\hline Men & $76(47.5)$ & $44(57,9)$ & $32(42.1)$ & 060 & 0495 \\
\hline Women & $84(52.5)$ & $52(61.9)$ & $32(38.1)$ & 0.00 & 0.495 \\
\hline \multicolumn{6}{|l|}{ BMI } \\
\hline$<18.8$ & $10(6.2)$ & $0(0)$ & $10(15.6)$ & & \\
\hline $18.5-24.9$ & $60(37.5)$ & $34(35.4)$ & $26(40.6)$ & 951 & $0023^{*}$ \\
\hline $25-29.9$ & $58(36.2)$ & $38(39.6)$ & $20(31.2)$ & & \\
\hline$\geq 30$ & $32(20.0)$ & $24(25)$ & $8(12.5)$ & & \\
\hline \multicolumn{6}{|l|}{ Diagnosis } \\
\hline Esophagus and stomach disease & $64(40.0)$ & $44(45.8)$ & $20(31.2)$ & & \\
\hline Liver and gallbladder disease & $34(21.2)$ & $28(29.2)$ & $6(9.4)$ & 197 & 0 001* \\
\hline Pancreatic disease & $10(6.2)$ & $10(10.4)$ & $0(0)$ & 19.1 & 0.001 \\
\hline Cancer & $52(32.5)$ & $14(14.6)$ & $38(59.4)$ & & \\
\hline
\end{tabular}

NRS = Nutritional Risk Screening 2002; BMI = body mass index; WHR = waist-to-hip ratio; *statistically significant difference at $\mathrm{p}<0.05$

pital stay, complications and mortality are reduced ${ }^{11}$. Considering the basic digestive system function of nutrient absorption and metabolism, patients with gastrointestinal diseases are more likely to develop malnutrition. The gastrointestinal system diseases that most commonly cause malnutrition are chronic inflammatory bowel diseases (ulcerative colitis and Crohn's disease), diverticulitis of digestive tract, chronic pancreatitis, chronic liver disease, and various types of malignant tumors ${ }^{12}$. Assessment of the nutritional status is recommended by nutritional guidelines, but has not yet become part of good clinical practice ${ }^{13-18}$. Several tests have been developed to identify patients at malnutrition risk ${ }^{19,20}$, among them, Nutritional Risk Screening (NRS-2002) is one of the simplest and most practical ones for screening nutritional status and assessment of nutritional risk in hospitalized patients ${ }^{21}$.

The aim of this study was to estimate the prevalence of nutritional risk by use of NRS-2002, both at hospital admission and discharge, as to better recognize patient nutritional needs. Furthermore, the aim was to estimate the percentage of patients who were provided nutritional support. We also wanted to analyze differences in patient anthropometry, biochemistry, gender and diagnoses, depending on whether or not they were at nutritional risk.

\section{Subjects and Methods}

\section{Subjects}

The study was conducted at the Department of Gastroenterology, Rijeka University Hospital Centre, between January and May 2017. Initially, 186 patients suffering from four different categories of gastrointestinal diseases (esophagus and stomach diseases, liver and gallbladder diseases, pancreatic diseases, and cancers) were recruited, but those with ascites, immobile patients, patients from intensive care unit, and preg- 
Table 2. Patient values of biochemical parameters according to nutritional risk status $(N=160)$

\begin{tabular}{|c|c|c|c|c|c|c|}
\hline & Reference range & $\begin{array}{l}\text { Total } \\
(\mathrm{N}=160)\end{array}$ & $\begin{array}{l}\text { NRS <3 } \\
(\mathrm{N}=96)\end{array}$ & $\begin{array}{l}\mathrm{NRS} \geq 3 \\
(\mathrm{~N}=64)\end{array}$ & t-test & $\mathrm{p}$ \\
\hline & & \multicolumn{5}{|c|}{ Mean (SD) } \\
\hline $\begin{array}{l}\text { Hemoglobin } \\
(\mathrm{g} / \mathrm{L})\end{array}$ & $119-157$ & $\begin{array}{l}113.9 \\
(21.3)\end{array}$ & $\begin{array}{l}114.8 \\
(22.8)\end{array}$ & $\begin{array}{l}112.7 \\
(19.0)\end{array}$ & 0.45 & 0.650 \\
\hline $\begin{array}{l}\text { Urea } \\
(\mathrm{mmol} / \mathrm{L})\end{array}$ & $2.8-8.3$ & \begin{tabular}{|l|}
6.8 \\
$(3.9)$
\end{tabular} & \begin{tabular}{|l|}
6.7 \\
$(4.1)$
\end{tabular} & \begin{tabular}{|l|}
7.3 \\
$(3.6)$
\end{tabular} & 0.62 & 0.536 \\
\hline $\begin{array}{l}\text { Creatinine } \\
(\mu \mathrm{mol} / \mathrm{L})\end{array}$ & $49-90$ & $\begin{array}{l}91.7 \\
(85.8) \\
\end{array}$ & \begin{tabular}{|l}
92.8 \\
$(102.3)$
\end{tabular} & \begin{tabular}{|l|}
90.0 \\
$(54.1)$ \\
\end{tabular} & 0.16 & 0.873 \\
\hline $\begin{array}{l}\text { Albumin } \\
(\mathrm{g} / \mathrm{L})\end{array}$ & $41-51$ & $\begin{array}{l}34.8 \\
(5.1)\end{array}$ & $\begin{array}{l}35.5 \\
(4.3)\end{array}$ & $\begin{array}{l}33.8 \\
(5.9)\end{array}$ & 1.47 & 0.146 \\
\hline $\begin{array}{l}\text { Cholesterol } \\
(\mathrm{mmol} / \mathrm{L})\end{array}$ & $<5.0$ & $\begin{array}{l}4.5 \\
(1.6)\end{array}$ & $\begin{array}{l}4.37 \\
(1.3)\end{array}$ & $\begin{array}{l}4.77 \\
(1.9)\end{array}$ & 1.05 & 0.301 \\
\hline $\begin{array}{l}\mathrm{HDL} \\
(\mathrm{mmol} / \mathrm{L})\end{array}$ & $>1.2$ & \begin{tabular}{|l|}
0.9 \\
$(0.3)$
\end{tabular} & $\begin{array}{l}0.97 \\
(0.3)\end{array}$ & $\begin{array}{l}1.07 \\
(0.4)\end{array}$ & 0.99 & 0.326 \\
\hline $\begin{array}{l}\mathrm{LDL} \\
(\mathrm{mmol} / \mathrm{L})\end{array}$ & $<3$ & \begin{tabular}{|l|}
2.8 \\
$(1.4)$
\end{tabular} & $\begin{array}{l}2.77 \\
(1.2)\end{array}$ & $\begin{array}{l}2.97 \\
(1.7)\end{array}$ & 0.76 & 0.446 \\
\hline $\begin{array}{l}\text { Triglycerides } \\
(\mathrm{mmol} / \mathrm{L})\end{array}$ & $<1.7$ & \begin{tabular}{|l}
1.5 \\
$(0.7)$
\end{tabular} & $\begin{array}{l}1.4 \\
(0.6)\end{array}$ & $\begin{array}{l}1.6 \\
(0.8)\end{array}$ & 0.89 & 0.376 \\
\hline
\end{tabular}

NRS = Nutritional Risk Screening 2002; HDL = high-density lipoprotein; LDL = low-density lipoprotein

nant women were excluded from the study. Then, 160 patients were eligible for the study and all of them filled out the NRS questionnaire. Patients were informed about the study and gave their informed written consent to participate in the investigation. The Ethics Committee of the Faculty of Health Sciences, University of Rijeka approved the study. The study was performed in accordance with ethical standards of the Declaration of Helsinki.

\section{Methods}

\section{Nutrition Risk Screening and nutritional support}

The Nutrition Risk Screening (NRS-2002) is a questionnaire designed to identify patients at nutritional risk and is a valid and reliable tool for assessing nutritional status of elderly patients in hospitals ${ }^{21}$. The initial NRS consists of four questions regarding body mass index $(\mathrm{BMI})\left(<18.8,18.5-20.5\right.$, and $\left.>20.5 \mathrm{~kg} / \mathrm{m}^{2}\right)$, weight loss history ( $>5 \%$ in 3 months, $>5 \%$ in 2 months or $>5 \%$ in 1 month), dietary intake $(0-25 \%, 25 \%-50 \%$, $50 \%-75 \%$ and $>75 \%$ ), and severity of disease. A nutrition score between 0 and 3 was given according to the recommendations for each criterion. The disease score was evaluated according to clinical evaluation, as fol- lows: patients with chronic illness with acute complications received 1 point; acute severe superimposed complications that made the patient bedridden received 2 points; and intensive care patients who were supposed to be given 3 points were excluded from the study. The minimal value of NRS-2002 is 7. The patients were considered at nutritional risk for scores equal or higher than 3. According to NRS-2002, patients were divided in two categories: those with nutritional risk (NRS <3) and those without nutritional risk (NRS $\geq 3)^{21}$. Patients were screened for NRS score at hospital admission and discharge. Nutritional support consisted of enteral and parenteral nutrition.

\section{Anthropometry}

Trained nurses measured patient body weight and body height using electronic scale (Seca, Hamburg, Germany), with body weight and body height accuracies of $\pm 0.1 \mathrm{~kg}$ and $\pm 0.5 \mathrm{~cm}$, respectively. BMI $\left(\mathrm{kg} / \mathrm{m}^{2}\right)$ was calculated from the values of body weight and body height. BMI was categorized into underweight $\left(<18.50 \mathrm{~kg} / \mathrm{m}^{2}\right)$, normal weight $\left(18.50-24.99 \mathrm{~kg} / \mathrm{m}^{2}\right)$, overweight $\left(25.00-29.99 \mathrm{~kg} / \mathrm{m}^{2}\right)$, and obese $(\geq 30 \mathrm{~kg} /$ $\left.\mathrm{m}^{2}\right)^{22}$. Waist and hip circumferences were measured 
Table 3. Comparison of anthropometric characteristics and nutritional risk status at hospital admission and discharge $(N=160)$

\begin{tabular}{|c|c|c|c|c|}
\hline & Admission & Discharge & t-test & $\mathrm{p}$ \\
\hline & \multicolumn{2}{|l|}{ Mean (SD) } & & \\
\hline Body weight $(\mathrm{kg})$ & $73.9(17.9)$ & $72.6(17.2)$ & 4.99 & 0.001 \\
\hline BMI $\left(\mathrm{kg} / \mathrm{m}^{2}\right)$ & $26.0(5.3)$ & $25.6(5.1)$ & 4.67 & 0.001 \\
\hline \multirow[t]{2}{*}{ WHR } & $0.94(0.1)$ & $0.93(0.1)$ & 0.32 & 0.750 \\
\hline & \multicolumn{2}{|l|}{ n (\%) } & Wilcoxon $\mathrm{Z} / \chi^{2}$-test & $\mathrm{p}$ \\
\hline $\begin{array}{l}\text { BMI } \\
<18.8 \\
18.5-24.9 \\
25-29.9 \\
\geq 30 \\
\end{array}$ & $\begin{array}{ll}10 & (6.2) \\
60 & (37.5) \\
58 & (36.3) \\
32 & (20)\end{array}$ & $\begin{array}{l}10(6.2) \\
68(42.5) \\
54(33.8) \\
28(17.5)\end{array}$ & 1.89 & $0.048^{*}$ \\
\hline $\begin{array}{l}\text { WHR } \\
<0.9 \\
0.9-0.95 \\
0.96-1 \\
>1\end{array}$ & $\begin{array}{ll}50 & (31.2) \\
42 & (26.2) \\
34 & (21.2) \\
34 & (21.2)\end{array}$ & $\begin{array}{ll}44 & (27.5) \\
38 & (23.8) \\
46 & (28.8) \\
32 & (20)\end{array}$ & 1.60 & $0.109^{* *}$ \\
\hline $\begin{array}{l}\text { NRS score } \\
\text { NRS }<3 \\
\text { NRS } \geq 3\end{array}$ & $\begin{array}{l}96(60.0) \\
64(40.0)\end{array}$ & $\begin{array}{l}102(63.8) \\
58(36.2)\end{array}$ & 68.24 & $0.001^{* *}$ \\
\hline
\end{tabular}

NRS = Nutritional Risk Screening 2002; BMI = body mass index; WHR = waist-to-hip ratio; SD = standard deviation; *Wilcoxon rank test significance; ${ }^{* *} \chi^{2}$-test significance

with an ergonomic tape Seca 1 (Seca, Hamburg, Germany). The range from 0 to $205 \mathrm{~cm}$ was used to calculate waist-to-hip ratio (WHR). WHR was categorized as normal (men $\leq 0.90$, women $\leq 0.85$ ) and large (men $>0.90$, women $>0.85)^{22}$.

\section{Biochemical parameters}

Blood samples were obtained from all patients at admission. The following parameters were evaluated by the standard biochemical methods: hemoglobin $(\mathrm{g} / \mathrm{L})$, urea $(\mathrm{mol} / \mathrm{L})$, creatinine $(\mu \mathrm{mol} / \mathrm{L})$, serum albu$\min (\mu \mathrm{mol} / \mathrm{L})$, cholesterol $(\mathrm{mmol} / \mathrm{L})$, high-density lipoprotein (HDL, mmol/L), low-density lipoprotein (LDL, mmol/L) and triglycerides $(\mathrm{mmol} / \mathrm{L})$.

\section{Statistical analysis}

All statistical analyses were performed using SPSS 16 statistical software (SPSS Inc., Chicago, IL, USA). Descriptive data were presented in percentages or mean with standard deviation (mean $\pm \mathrm{SD}$ ). To investigate differences between groups, the $\chi^{2}$-test was per- formed for categorical measurements and t-tests for independent samples. For continuous variables, $t$-test for dependent samples and Wilcoxon test were applied. The level of statistical significance was set at $95 \%$ $(\mathrm{p}<0.05)$.

\section{Results}

In our study, 160 patients were evaluated by NRS score. There were 84 (52.5\%) women and 76 (47.5\%) men, mean age $68.8 \pm 13.3$ years. Distribution of gastrointestinal diseases among patients revealed esophagus and stomach diseases in $40 \%$, liver and gallbladder diseases in $17 \%$, pancreatic diseases in $5 \%$, and cancer in $26 \%$ of patients. At admission, $53.1 \%$ of patients had malnutrition and $18.8 \%$ of patients were not at risk, however, both of these categories received nutritional support. At discharge, the percentages increased to $65.6 \%$ of patients with malnutrition and $22.9 \%$ of patients without risk, having received dietary support (Figs. 1 and 2, Table 4). 


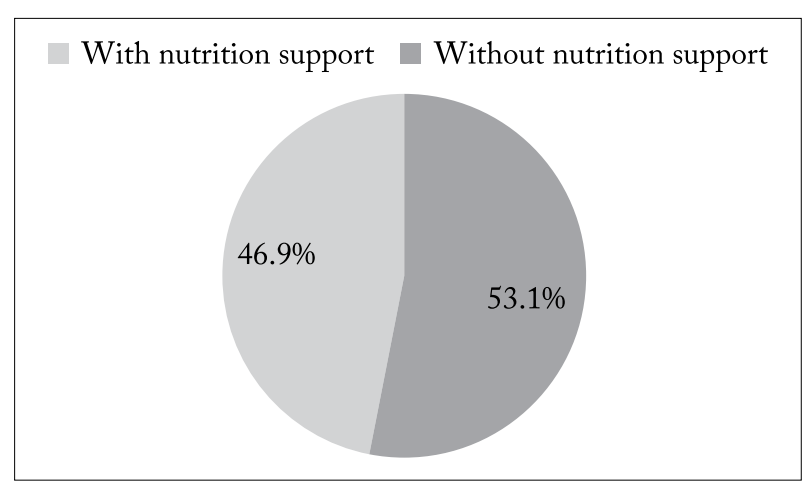

Fig. 1. Malnutrition risk patients with nutrition support at admission.

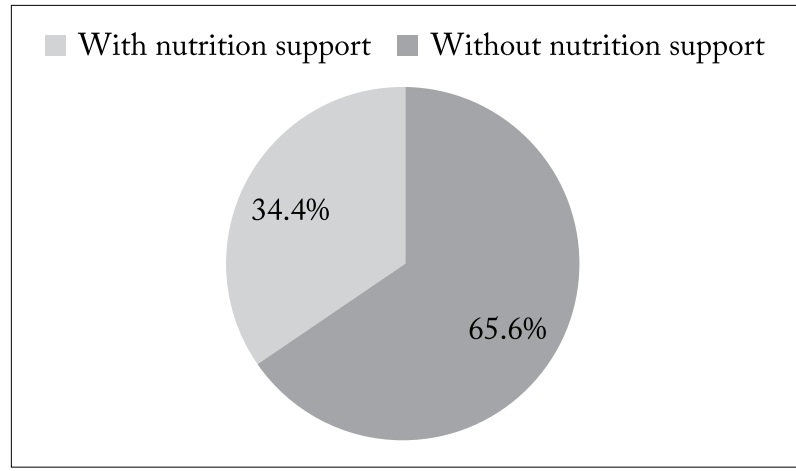

Fig. 2. Malnutrition risk patients with nutrition support at discharge.

Table 4. Diet difference among patients according to nutritional risk status and hospital admission and discharge $(N=160)$

\begin{tabular}{|c|c|c|c|c|c|}
\hline & & NRS $<3$ & NRS $\geq 3$ & $\chi^{2}$-test & $\mathrm{p}$ \\
\hline \multirow{10}{*}{ Admission } & Oral nutrition & n (\%) & n (\%) & & \\
\hline & Ulcerative & $22(22.9)$ & $22(34.4)$ & \multirow{7}{*}{$6.54^{*}$} & \multirow{7}{*}{0.080} \\
\hline & Bilious, pancreatic & $28(29.2)$ & $14(21.9)$ & & \\
\hline & Hepatoprotective & $4(4.2)$ & $0(0)$ & & \\
\hline & Light & $6(6.2)$ & $8(12.5)$ & & \\
\hline & Tea diet & $34(35.4)$ & $10(15.6)$ & & \\
\hline & Liquid diet & $2(2.1)$ & $6(9.4)$ & & \\
\hline & Mixed diet & $0(0)$ & $4(6.2)$ & & \\
\hline & Enteral nutrition & $18(18.8)$ & $24(37.5)$ & 3.49 & $0.045^{* *}$ \\
\hline & Parenteral nutrition & $0(0.0)$ & $10(15.6)$ & & \\
\hline \multirow{10}{*}{ Discharge } & Oral nutrition & & & & \\
\hline & Ulcerative & $40(41.7)$ & $30(46.9)$ & \multirow{7}{*}{$10.14^{*}$} & \multirow{7}{*}{$0.006^{* *}$} \\
\hline & Bilious, pancreatic & $46(47.9)$ & $12(18.8)$ & & \\
\hline & Hepatoprotective & $6(6.2)$ & $2(3.1)$ & & \\
\hline & Light & $4(4.2)$ & $12(18.8)$ & & \\
\hline & Tea diet & $0(0)$ & $0(0)$ & & \\
\hline & Liquid diet & $0(0)$ & $2(3.1)$ & & \\
\hline & Mixed diet & $0(0)$ & $6(9.4)$ & & \\
\hline & Enteral nutrition & $22(22.9)$ & $42(65.6)$ & 19.91 & $0.001^{* *}$ \\
\hline & Parenteral nutrition & $0(0.0)$ & $0(0.0)$ & & \\
\hline
\end{tabular}

NRS = Nutritional Risk Screening 2002; *when calculating $\chi^{2}$ of a category test with less than 5 examinees, they are merged into one; ** statistically significant difference at $\mathrm{p}<0.05$

The mean BMI was $25.9 \pm 5.3 \mathrm{~kg} / \mathrm{m}^{2}$, only $6.2 \%$ of patients were underweight, while the majority of $56.2 \%$ of patients were overweight or obese. Patients at nutrition risk were significantly older $(\mathrm{p}=0.014)$ and had lower BMI than patients without nutritional risk $(\mathrm{p}=0.023)$ (Table 1).
The mean length of stay was significantly higher in patients with nutritional risk (14 days) as compared to non-risk group (11 days) ( $\mathrm{p}=0.037)$ (Table 1). Considering the length of hospital stay, $46.2 \%$ of patients stayed in the hospital for $10-15$ days, $33.8 \%$ for $5-10$ days, and $20 \%$ for more than 15 days. 
The mean albumin value was $34.8 \mathrm{~g} / \mathrm{L}$. Although no statistical significance was observed, patients without nutritional risk had higher albumin values (35.5 $\mathrm{g} / \mathrm{L})$ compared to patients at risk $(33.8 \mathrm{~g} / \mathrm{L})$. When the values of biochemical parameters were compared between the two categories of patients, no statistically significant differences were found (Table 2). Compared to other diagnoses, nutritional risk was significantly higher in cancer patients $(\mathrm{p}=0.001)$ (Table 1$)$.

Table 3 illustrates comparison of anthropometric characteristics and nutritional risk status of patients at hospital admission and discharge. Patient body weight and BMI were significantly lower at discharge from the hospital than at admission ( $\mathrm{p}=0.001$ both). The percentage of patients with nutritional risk was $40 \%$ at admission, which was significantly higher in comparison with $36.2 \%$ of risk patients at discharge $(\mathrm{p}=0.001)$ (Table 3$)$.

Out of 64 patients with nutrition risk, 24 (37.5\%) of them received enteral nutrition (oral nutrition with supplements) and $10(15.6 \%)$ received parenteral nutrition. At discharge from the hospital, 42 patients with nutrition risk received enteral nutrition, which was significantly higher compared to 24 patients with enteral nutrition at admission $(p=0.001)$. None of the patients received parenteral nutrition at discharge. Furthermore, enteral nutrition was significantly higher in patients with nutritional risk compared to non-risk patients both at admission and discharge $(\mathrm{p}<0.045$ and $\mathrm{p}<0.001$, respectively). According to NRS-2002, statistically significant difference was found between the two patient categories according to the type of oral diet. This significance referred to non-risk patients, who consumed more ulcerative and bilious pancreatic diet at discharge, while patients at nutritional risk consumed more liquid and mixed diet $(\mathrm{p}=0.006)$ (Table 4).

\section{Discussion}

According to our knowledge, this is one of the rare studies in Croatia and the only one conducted at the Rijeka University Hospital Centre, which documented the prevalence of malnutrition risk in gastroenterological patients. A similar study by Vranešić Bender et al. from 2010 had a remarkable number of patients, but it was published a decade ago, and nutritional status in patients was assessed only at admission, which is limiting, since they lack data of the nutritional status of discharged patients ${ }^{23}$.
According to previous research data, the prevalence of malnutrition ranges from $20 \%$ to $80 \%$ of patients admitted to the hospital ${ }^{9,10,16,24,25}$. Our results indicated $40 \%$ of patients with malnutrition risk at admission, which is a lower rate of malnutrition than in the abovementioned Croatian study that used Subjective Global Assessment for nutritional status calculation. Nevertheless, our results are comparable to other studies which used NRS-2002 to quantify the prevalence of malnutrition risk, and the majority of them have reported similar findings $s^{2,9,13,24,26}$, with the exception of the Romanian gastroenterology study, which showed a lower rate of malnutrition risk $(17.1 \%)^{4}$.

Malnutrition risk is usually associated with older age, as previously reported from numerous studies ${ }^{2,16,27}$, and additionally confirmed by our results. The mean age of our patients was 68.8 years. Except for the fact that malnutrition risk increases with age, it is also significantly higher in patients with lower $\mathrm{BMI}^{1,4,7}$. On the other hand, the risk of malnutrition could also be found in patients whose $\mathrm{BMI}$ is normal or even higher than $25 \mathrm{~kg} / \mathrm{m}^{2},{ }^{22,27}$, which along with our results in $\mathrm{pa}-$ tients with low BMI and reduced risk of malnutrition at discharge, additionally confirms that BMI should not be the only tool for malnutrition risk assessment $^{28,29}$. For appropriate nutritional status evaluation, many biochemical parameters are recommended, including hemoglobin, urea, creatinine, lipid status, and albumin $^{8,23,30}$. Although many studies have reported decreased albumin level in malnourished patients, serum albumin level in our patients did not significantly differ between those with malnutrition risk $(33.8 \mathrm{~g} / \mathrm{L})$ and those without malnutrition risk $(35.5 \mathrm{~g} / \mathrm{L})$. Similar levels of serum albumin have been reported by $\mathrm{Co}^{-}$ vinsky et al. ${ }^{29}$. Nevertheless, our results indicate that the average albumin level was lower than $35 \mathrm{~g} / \mathrm{L}$, which is, according to some researchers, indicative of increased postoperative morbidity and mortality ${ }^{31}$. Considering the latter and knowing that various diseases and postoperative conditions affect serum albumin level, this serum protein should not be proposed as an isolated parameter for nutritional status assessment $^{32}$.

Patients with malnutrition risk were hospitalized for longer time than non-risk patients, which corresponds to many other studies ${ }^{1,16,13,27}$. In addition, close correlation was found between various diseases and risk of malnutrition ${ }^{16,33}$. For example, Pirlich et al. 
found the incidence of malnutrition to be significantly higher in malignant diseases than it was in non-malignant diseases and inflammatory bowel diseases ${ }^{16}$. We analyzed the incidence of malnutrition risk in various gastrointestinal diseases and our findings revealed that malnutrition risk was significantly higher in cancers, which corresponds and additionally supports the above-mentioned data ${ }^{32}$. With respect to all said above, it can be concluded that the main predictors of malnutrition risk are older age, gastrointestinal diseases, and malignant tumors ${ }^{4,32,34}$.

Out of all patients with recognized malnutrition risk (NRS $\geq 3$ ), approximately half (53\%) received nutritional support. During hospital stay, an additional number of patients were found to be malnourished, which contributed to the higher percentage of risk patients with nutritional support at discharge (65.6\%). A Danish study, for instance, reports only $25 \%$ of hospitalized patients at risk who received dietary suppor ${ }^{1}$.

At discharge, $34.4 \%$ of patients with malnutrition were not adequately nourished but $22.9 \%$ of the nonrisk patients received nutritional support. The reason why all malnourished patients were not nutritionally supported, while at the same time some of the nonrisk patients were, could be found in inappropriate implementation of screening tests for malnutrition in hospitals. Applying screening programs for malnutrition depends on the organization of the health care system itself and the hospital management policy. In the existing frameworks, when clinical nutrition enters through a small door into Croatian health care, the lack of necessary staff, inadequate medical education, and insufficient collaboration between doctors and clinical nutritionists might be the reason why malnutrition is still unrecognized and not treated in a certain percentage of hospitalized patients.

With this work, we want to raise awareness in the health care circles of the importance of conducting malnutrition risk tests to raise the quality of medical care for hospitalized patient and to try to influence the existing deficiencies, hoping for assessment of nutritional risk to become mandatory for the health care system in Croatia and beyond.

A limitation of this study was a small number of patients, especially those with particular diagnoses.

The main predictors of malnutrition risk are prolonged hospital stay, older age, and malignant tumors. Screening for malnutrition risk should be implement- ed among gastrointestinal patients, as to provide nutritional support for all those patients who are at risk.

\section{References}

1. Kondrup J, Johansen N, Plum LM, Bak L, Hojlund Larsen I, Martinsen A, et al. Incidence of nutritional risk and causes of inadequate nutritional care in hospitals. Clin Nutr. 2002 Dec;21(6):461-8, https://doi.org/10.1054/clnu.2002.0585.

2. Rizzi M, Mazzuoli S, Regano N, Inguaggiato R, Bianco M, Leonardo $\mathrm{G}$, et al. Undernutrition, risk of malnutrition and obesity in gastroenterological patients: a multicenter study. World J Gastrointest Oncol. 2016 Jul 15;8(7):563-72, http:// doi.org/10.4251/wjgo.v8.i7.563.

3. Holmes S. Undernutrition in hospital patients. Nurs Stand. 2003 Jan 22-28;17(19):45-52; quiz 54-5, https://doi.org/ 10.7748/ns2003.01.17.19.45.c3333.

4. Gheorghe C, Pascu O, Iacob R, Vadan R, Iacob S, Goldis A, et al. Nutritional risk screening and prevalence of malnutrition on admission to gastroenterology departments: a multicentric study. Chirurgia (Bucur). 2013 Jul-Aug;108(4):535-41.

5. Pérez de la Cruz A, Lobo Támer G, Orduña Espinosa R, Mellado Pastor C, Aguayo de Hoyos E, Ruiz López MD. Malnutrition in hospitalized patients: prevalence and economic impact. Med Clin (Barc). 2004 Jul 10;123(6):201-6, https://doi. org/10.1016/ S0025-7753(04)74461-9.

6. Beck AM, Balknäs UN, Fürst P, Hasunen K, Jones L, Keller U, et al. Food and nutritional care in hospitals: how to prevent undernutrition - report and guidelines from the Council of Europe. Clin Nutr. 2001 Oct;20(5):455-60, https://doi. org/10.1054/clnu.2001.0494.

7. Tan R, Long J, Fang S, Mai H, Lu W, Liu Y, et al. Nutritional Risk Screening in patients with chronic kidney disease. Asia Pac J Clin Nutr. 2016;25(2):249-56. https://doi.org/ 10.6133/ apjen.2016.25.2.24.

8. Zhou J, Wang M, Wang H, Chi Q. Comparison of two nutrition assessment tools in surgical elderly inpatients in northern China. Nutr J. 2015 Jul 14;14:68, http://doi.org/10.1186/ s12937-015-0054-8.

9. Rasmussen HH, Kondrup J, Staun M, Ladefoged K, Kristensen $\mathrm{H}$, Wengler A. Prevalence of patients at nutritional risk in Danish hospitals. Clin Nutr. 2004 Oct;23(5):1009-15, https://doi.org/10.1016/j.clnu.2004.01.001.

10. Waitzberg DL, Caiaffa WT, Correia MI. Hospital malnutrition: the Brazilian national survey (IBRANUTRI): a study of 4000 patients. Nutrition. 2001 Jul-Aug;17(7-8):573-80, https: //doi.org/10.1016/S0899-9007(01)00573-1.

11. Stratton RJ, Green CJ, Elia M. Disease-related malnutrition: an evidence-based approach to treatment. Br J Nutr. 2004 Apr;91:651-2, https://doi.org/10.1079/BJN20031059.

12. Sobotka L, editor. Basics in Clinical Nutrition. Prague: Publishing House Galén and ESPEN; 2004.

13. Konturek PC, Herrmann HJ, Schink K, Neurath MF, Zopf Y. Malnutrition in hospitals: it was, is now, and must not remain a 
problem! Med Sci Monit. 2015 Oct 2;21:2969-75, http://doi. org/10.12659/MSM.894238.

14. Stratton RJ, Hackston A, Longmore D, Dixon R, Price S, Stroud M, et al. Malnutrition in hospital outpatients and inpatients: prevalence, concurrent validity and ease of use of the 'malnutrition universal screening tool' ('MUST') for adults. Br J Nutr. 2004 Nov;92(5):799-808, https://doi.org/10.1079/ BJN20041258.

15. Mowe M, Bosaeus I, Rasmussen HH, Kondrup J, Unosson M, Rothenberg E, et al. Insufficient nutritional knowledge among health care workers? Clin Nutr. 2008 Apr;27(2):196-202, https://doi.org/10.1016/j.clnu.2007.10.014.

16. Pirlich M, Schütz T, Norman K, Gastell S, Lübke HJ, Bischoff SC. The German hospital malnutrition study. Clin Nutr. 2006 Aug;25(4):563-72, https://doi.org/10.1016/j.clnu.2006.03.005.

17. Correia MI, Waitzberg DL. The impact of malnutrition on morbidity, mortality, length of hospital stay and cost evaluated trough a multivariate model analysis. Clin Nutr. 2003 Jun;22(3):235-9, https://doi.org/10.1016/S0261-5614(02)00215-7.

18. Kyle UG, Pirlich M, Schuetz T, Luebke HJ, Lochs H, Pichard C. Prevalence of malnutrition in 1760 patients at hospital admission: a controlled population study of body composition. Clin Nutr. 2003 Oct;22(5):473-81, https://doi.org/10.1016/ S0261-5614(03)00049-9.

19. Sorensen J, Kondrup J, Prokopowicz J, Schiesser M, Krähenbühl L, Meier R, Liberda M. EuroOOPS: an international, multicentre study to implement nutritional risk screening and evaluate clinical outcome. Clin Nutr. 2008 Jun;27(3):340-9, https://doi.org/10.1016/j.clnu.2008.03.012.

20. Velasco C, García E, Rodríguez V, Frias L, Garriga R, Alvarez $\mathrm{J}$, et al. Comparison of four nutritional screening tools to detect nutritional risk in hospitalized patients: a multicentre study. Eur J Clin Nutr. 2011 Feb;65(2):269-74, https://doi. org/10.1038/ejcn.2010.243.

21. Kondrup J, Rasmussen HH, Hamberg O, Stanga Z. Nutritional risk screening (NRS 2002): a new method based on an analysis of controlled clinical trials. Clin Nutr. 2003 Jun;22(3): 321-36, https://doi.org/10.1016/S0261-5614(02)00214-5.

22. WHO. Obesity: Preventing and managing the global epidemic. Report of a WHO Consultation. WHO Techn Rep Ser. 894. Geneva: WHO, 2000.

23. Vranešić Bender D, Krznarić Z, Colić Barić I. Assessment of nutritional status of gastroenterology patients in Croatia. Coll Antropol. 2010 Dec;34(4):1329-34.

24. Edington J, Boorman J, Durrant ER, Perkins A, Giffin CV, James R, et al. Prevalence of malnutrition on admission to four hospitals in England. The Malnutrition Prevalence Group. Clin Nutr. 2000 Jun;19(3):191-5, https://doi.org/10.1054/ clnu.1999.0121.

25. Imoberdorf R, Meier R, Krebs P, Hangartner PJ, Hess B, Stäubli M, et al. Prevalence of undernutrition on admission to Swiss hospitals. Clin Nutr. 2010 Feb;29(1):38-41, https://doi. org/10.1016/j.clnu.2009.06.005.

26. Comi D, Palmo A, Brugnani M, D'Amicis A, Costa A, D'Andrea F, et al. The hospital malnutrition Italian study. Clin Nutr. 1998 Aug;17(1):52, https://doi.org/10.1016/S02615614(98)80239-2.

27. Gökcan H, Selçuk H, Töre E, Gülseren P, Cambaz H, Sarıtaş Ş, et al. The Nutritional Risk Screening 2002 tool for detecting malnutrition risk in hospitalised patients: perspective from a developing country. Turk J Gastroenterol. 2014 Dec;25(6):71823, https://doi.org/ 10.5152/tjg.2014.6651.

28. Stobäus N, Pirlich M, Valentini L, Schulzke JD, Norman K. Determinants of bioelectrical phase angle in disease. Br J Nutr. 2012 Apr;107(8):1217-20, https://doi.org/10.1017/S0007114 511004028.

29. Covinsky KE, Covinsky MH, Palmer RM, Sehgal AR. Serum albumin concentration and clinical assessments of nutritional status in hospitalized older people: different sides of different coins? J Am Geriatr Soc. 2002 Apr;50(4):631-7, https://doi. org/10.1046/j.1532-5415.2002.50156.x.

30. Sungurtekin H, Sungurtekin U, Balci C, Zencir M, Erdem E. The influence of nutritional status on complications after major intraabdominal surgery. J Am Coll Nutr. 2004 Jun;23(3):22732, https:// doi: 10.1080/07315724.2004.10719365.

31. Fuhrman MP, Charney P, Mueller CM. Hepatic proteins and nutrition assessment. J Am Diet Assoc. 2004 Aug;104(8):125864, https://doi.org/10.1016/j.jada.2004.05.213.

32. Ravasco P, Monteiro-Grillo I, Vidal PM, Camilo ME. Nutritional deterioration in cancer: the role of disease and diet. Clin Oncol (R Coll Radiol). 2003 Dec;15(8):443-50, https://doi. org/10.1016/S0936-6555(03)00155-9.

33. Pineda JCC, Garcia G, Velasco N, Graf JIDP, Adames AM, Mijan de la Tore A. Nutritional assessment of hospitalized patients in Latin America: association with prognostic variables. The ENHOLA study. Nutr Hosp. 2016 May-Jun;33(3):656-62. http://dx.doi.org/10.20960/nh.275.

34. Martín Palmero Á, Serrano Pérez A, Chinchetru Ranedo MJ, Cámara Balda A, Martínez de Salinas Santamarí MÁ, Villar García G, et al. Malnutrition in hospitalized patients: results from La Rioja. Nutr Hosp. 2017 Mar 30;34(2):402-6, http:// dx.doi.org/10.20960/nh.458. 


\title{
Sažetak
}

\section{PROCJENA NUTRITIVNOG RIZIKA KOD GASTROENTEROLOŠKIH BOLESNIKA U KLINIČKOM BOLNIČKOM CENTRU RIJEKA}

\author{
S. Pavičić Žeželj, D. Malec, D. Janko Labinac, T. Šoić Vranić, G. Mičetić Balog, T. Schnurrer-Luke-Vrbanic, T. Čaljkušic Mance, \\ D. Kovačević i O. Crijanović Peloza
}

Malnutricija se povezuje s nekim bolestima kao što su upalna bolest crijeva, kronični pankreatitis, kronična bolest jetre i zloćudni tumori. Kod malnutricije dolazi do gubitka težine, manjka proteina te nedostatka nekih specifičnih hranjivih tvari. Cilj ovoga rada bio je procijeniti učestalost nutritivnog rizika kod 160 gastroenteroloških bolesnika metodom procjene nutritivnog rizika (NRS-2002) pri prijmu i otpustu bolesnika. Bolesnici su boravili u bolnici između 5 i 15 dana ili duže. Rezultati su pokazali da je kod prijma u bolnicu $40 \%$, a na otpustu $36,2 \%$ bolesnika bilo pothranjeno. Na prijmu je $53,1 \%$ pothranjenih bolesnika dobilo odgovarajuću nutritivnu potporu, dok $34,4 \%$ bolesnika nije dobilo takvu potporu pri otpustu iz bolnice. Pothranjeni bolesnici bili su značajno mlađi, imali su značajno niži indeks tjelesne mase, značajno su dulje boravili u bolnici te su češće bolovali od zloćudnih bolesti. Procjena nutritivnog rizika treba biti rutinska kako bi se osigurala odgovarajuća nutritivna potpora za sve bolesnike koji su u riziku od malnutricije.

Ključne riječi: Pothranjenost; Gastroenterološki bolesnici; Nutritiona procjena rizika (NRS 2002) 